\title{
DESAFIOS ESTRATÉGICOS DA IGREJA CATÓLICA
}

DERMI AZEVEDO

O fim do eurocentrismo eclesiástico, o avanço dos fenômenos da deseclesialização e da secularização, a persistência do déficit democrático interno e a concorrência simultânea dos novos agrupamentos religiosos e da expansão do Islamismo, são alguns dos desafios estratégicos enfrentados pela Igreja Católica Apostólica Romana, neste início de século. Esses dados da realidade ganham uma ênfase ainda maior, no momento em que se aproxima a eleição do novo papa, a quem caberá dirigir o processo de manutenção ou de mudança na linha pastoral e política adotada, nos últimos 25 anos, por João Paulo II.

Internamente, a Igreja continua a enfrentar temas polêmicos, tais como o controle da natalidade, o celibato obrigatório para o clero, o reaproveitamento dos padres casados nas atividades eclesiais, o acesso das mulheres ao sacerdócio, a ordenação de homens casados, as questões de gênero e da homossexualidade, o diálogo ecumênico e inter-religioso, o casamento de católicos divorciados e sua participação nos sacramentos e na comunidade católica, as mudanças na liturgia e as inovações científicas, incidindo especialmente no campo da bioética. Outro tema estratégico que resulta, cada vez mais, em pressões sobre o governo central da Igreja Católica, refere-se ao relacionamento entre a cúpula eclesiástica e as igrejas regionais e locais.

Sete tópicos serão abordados neste texto, para tratar dos desafios colocados à Igreja: o primeiro é uma caracterização idealtípica da Igreja Católica, como instituição, destacando-se seus pólos de poder e sua forma de governo. O segundo são as mudanças no cenário religioso moderno e contemporâneo, com ênfase para a interação entre o Catolicismo, a modernidade e a pós-modernidade; as metamorfoses do sagrado; o fim do eurocentrismo eclesiástico e as mudanças no cenário religioso latino-americano e brasileiro. $\mathrm{O}$ terceiro tópico é a persistência do défícit democrático inter- 
no do Catolicismo, traduzido, entre outros indicadores, pelas restrições à livre investigação teológica. O quarto são os desafios específicos da realidade da Igreja, à luz do Concílio Vaticano II (1962-1965), um evento histórico que procurou responder às questões da modernidade, sobretudo em seus aspectos sociopolíticos; no entanto, apesar dos avanços conciliares, acentuou-se, nesses últimos quase quarenta anos, a contradição entre os valores modernos, reconhecidos pela Igreja na sua missão ad extra, e as suas estruturas e práticas ad intra. Isso se revela, por exemplo, na continuidade do défícit democrático intra-eclesiástico. O quinto tópico é o pontificado de João Paulo II, sobre o qual se apresentará um breve balanço. O sexto é a política externa do Vaticano, com uma referência específica ao caráter político-pastoral das viagens do papa. O sétimo e último tópico é o atual panorama pré-eleitoral na ICR, relacionado à sucessão de João Paulo II, com algumas referências à Igreja latino-americana. Nessa última, como se sabe, foi sistematizada a Teologia da Libertação. Na conclusão, sintetiza-se a pauta das mudanças reivindicadas por vários setores dessa Igreja, com vistas ao fortalecimento da posição eclesial em plena crise mundial de valores e de referências existenciais.

\section{CARACTERÍSTICAS DAIGREJA COMO INSTITUIÇÃO}

\section{Os pólos de poder}

A Igreja Católica Romana (ICR) é uma das mais antigas instituições do mundo: é herdeira do Império Romano e da Idade Média. Vive, simultaneamente, três tempos: a) o tempo cotidiano, aquele da sociedade como um todo; b) o tempo histórico, que se estende por dois mil anos de existência; e 3) o tempo mítico, o de sua mensagem religiosa propriamente dita. A ICR tem, também, uma tríplice leitura do espaço: a) um espaço restrito, a diocese onde é exercido o poder dos bispos; b) um espaço mais amplo, a igreja universal, com sede em Roma; e c) um espaço mítico, religioso propriamente dito. (Roy, 1990)

Para facilitar a compreensão da arena eclesiástica católica, elaborei, à luz de Weber, seis tipos ideais de pólo de poder intra-eclesiástico. Defino os pólos de poder como instâncias dialéticas, cujos atores interagem e disputam a hegemonia interna das instituições. $\mathrm{Na}$ arena católica, o poder divide-se, assimetricamente, entre seis pólos: 1) o pólo pontifício, representado pelo papa, que a doutrina católica considera sucessor do após- 
tolo Pedro; 2) o pólo episcopal, representado pelo bispos, 3) o pólo burocrático central, representado pela Cúria Romana; 4) o pólo das ordens e congregações religiosas; 5) o pólo dos leigos; e 6) o pólo da sociedade civil intra-eclesiástica, que abrange pessoas, idéias e propostas dos pólos anteriores, e explicita a emergência de uma sociedade civil, nacional e internacional, dentro da própria Igreja.

Detalhemos um pouco as características desses pólos. O pólo pontifício é o principal ponto de referência da instituição eclesiástica. $\mathrm{O}$ papa é, ao mesmo tempo, o bispo de Roma e o primus inter pares do conjunto do episcopado mundial. Na estrutura institucional da Igreja, os bispos (pólo episcopal) estão para as suas comunidades específicas, assim como o papa está para a Igreja em todo o mundo. Seu papel, e também o dos padres, é o de realizar três funções principais: o anúncio oficial da mensagem bíblica, a administração dos sacramentos e a liderança da comunidade, favorecendo a sua dimensão unitária. Cabe também aos bispos garantir a autenticidade da transmissão da mensagem cristã. No aspecto legal, assim como o papa tem jurisdição sobre o conjunto da Igreja, os bispos a possuem sobre as suas dioceses e os padres sobre suas paróquias. Dessa forma, ela reproduz, mutatis mutandis, o modelo geográfico-administrativo do Império Romano.

O pólo burocrático, representado pela Cúria Romana, é historicamente o segundo e, às vezes, até mesmo o primeiro detentor de poder na estrutura da Igreja. Desde a Idade Média, a Cúria Romana vem cuidando dos interesses materiais, jurídicos, doutrinários e disciplinares da Igreja, por meio de seus vários dicastérios (como são chamados os ministérios do governo central da Igreja). Foi a Cúria que administrou a Inquisição, que se tornaria, em 1542, a Congregação do Santo Ofício, com o objetivo de assegurar, inclusive com o uso da força e de tratamentos cruéis e desumanos, a ortodoxia da Doutrina Católica. Com o Concílio Vaticano II, o Santo Ofício passou a ser chamado de Congregação para a Doutrina da Fé. A última reforma curial foi feita por João Paulo II, em 1984. Depende da Cúria toda a administração central do Catolicismo, inclusive a tramitação dos processos para a nomeação dos bispos e para a tramitação de outros processos contra teólogos considerados heterodoxos, do ponto de vista doutrinário.

O pólo representado pelas ordens e congregações religiosas, como uma configuração, no sentido dado a essa palavra por Norbert Elias, não pode ser reduzido, de forma simplista, ao modus operandi da igreja institucional: elas nem são diretamente subordinadas à hierarquia clerical, nem, contudo, são entidades totalmente autônomas. As ordens e as congregações religiosas 
são grupos voluntários integrados por pessoas reunidas por contrato, voltadas para motivos comuns e dotadas de uma organização interna baseada na associação, no compromisso e em motivações fundamentadas em determinados ideais. Representam um agrupamento voluntário utópico (Turcotte, 1990), com um caráter colegiado, do ponto de vista administrativo.

O quinto pólo, representado pelos leigos, até recentemente constituía uma espécie de Terceiro Estado na estrutura da Igreja, subordinado à escala hierárquica que vai dos padres, aos bispos e ao papa. Sua situação passou a mudar, progressivamente, com o Concílio Vaticano II, no início dos anos 60, que lhes garantiu o estatuto de sujeitos de direito na Igreja. O sexto pólo, correspondente à emergência de uma sociedade civil intra-eclesiástica, reúne pessoas, grupos e movimentos oriundos de todos os demais pólos, de forma transversal. A idéia unitária e diversificada que move esse pólo corresponde aos ideais do Concílio Vaticano II, cujo principal paradigma, de acordo com os documentos oficiais do conclave, é o de uma Igreja a serviço da causa da humanidade, em todas suas dimensões, e aberta ao diálogo inter-religioso.

\section{Forma de governo da Igreja}

Esses pólos de poder intra-eclesiásticos sugerem, pelo menos, três questões fundamentais sobre a forma de governo central da Igreja: a primeira é a adequação ou não das formas clássicas de governo a essa instituição, ao mesmo tempo religiosa e política. Podemos afirmar que estamos diante de uma monarquia? De uma teocracia? Poderia ser chamada de uma oligarquia? Nas estruturas e práticas dessa instituição, prevalece ou não o padrão clássico de uma democracia?

A resposta oficial da Igreja a essas questões, em vários estudos e documentos, estabelece uma simbiose entre referências teológicas e referências políticas, ao enfatizar que nenhuma forma política válida para um Estado pode também valer para a Igreja, por não se tratar de uma instituição exclusivamente temporal. "A Santa Sé - afirma documento da Secretaria de Estado do Vaticano - não constitui um poder temporal, com finalidades políticas, mas uma autoridade moral". Estudos eclesiológicos indicam, por outra parte, que, pelo menos em seus primórdios, prevalecia na comunidade cristã pré-constantiniana um conjunto de práticas com as características da democracia direta.

A segunda pergunta refere-se à preponderância de algum desses pólos sobre os demais, em termos de hegemonia, e quais as consequiências 
derivadas disso. A realidade mostra que, embora os princípios da vivência comunitária e da colegialidade tenham sido aprovados pelo Concílio Vaticano II, o exercício do poder na Igreja ainda se concentra, principalmente, nos pólos pontifício e burocrático-curial. Veremos, mais adiante, que, em termos geopolíticos, a Igreja já deixou de ser eurocêntrica, embora o governo eclesiástico continue centralizado no Vaticano. A terceira pergunta refere-se à intersecção entre essa dinâmica interna da Igreja e as relações exteriores do Vaticano e da Santa Sé, de que trataremos adiante.

\section{MUDANÇAS NO CENÁRIO RELIGIOSO}

\section{Catolicismo: modernidade e pós-modernidade}

Uma das características mais destacadas de uma sociedade moderna, com relação a sociedade tradicional, é a progressiva diferenciação entre as pessoas, suas atividades e seus conhecimentos, com base na razão instrumental, na separação entre Igreja e Estado e no laicismo. O indivíduo e o individualismo constituem sua principal referência. Essa visão do ser humano e do mundo contrasta com a cosmovisão cristã e católica, em que a interação do ser humano com a natureza e com outros seres humanos dáse em relação a um princípio superior, a uma religião ou a algum tipo de espiritualidade.

O Cristianismo baseia-se, essencialmente, numa utopia unitária e não fragmentada. Em contrapartida, a sociedade moderna é fragmentada e fragmentária, e não reconhece a submissão, sem prévio debate, do indivíduo a qualquer verdade ou autoridade. Aposta na democracia como modelo ideal, mesmo que se trate de uma democracia meramente procedimental e formal. Durante vários séculos, a Igreja entendeu a modernidade como um movimento anticatólico, que remonta à Reforma protestante, ao Iluminismo e à Revolução Francesa. Essa visão negativa da modernidade foi levada ao extremo pelo tradicionalismo católico, do qual Joseph de Maistre foi um dos principais representantes. Contrariando essa perspectiva, o Concílio Vaticano II, no início dos anos 60, oficializou o diálogo com o mundo moderno e reconheceu os direitos humanos como referência ética, política e jurídica.

A pós-modernidade reforça o individualismo e representa um modo de viver e de pensar desencantado diante da razão, optando por uma ética sempre provisória e por uma moral do imediatismo. No campo religioso, impõem-se dois processos contraditórios: de um lado, ganha força o 
caráter privado da crença e das práticas religiosas e, de outro, assiste-se ao processo do "politeismo pós-cristão" (Bazán, 1991), em que a busca de sentido dirige-se para as práticas esotéricas. O consumismo também assume um caráter prático religioso.

O desafio da modernidade não atinge apenas o Cristianismo, mas todas as religiões. Todas elas são pressionadas a passar do pensamento simbólico, que identifica a realidade com o símbolo, a um pensamento analítico, que dá um caráter imanentista à origem dos fenômenos físicos e sociais. Essa passagem é difícil e implica um processo de perda da credibilidade das expressões e crenças religiosas (Días-Salazar, 2002). No entanto, um desafio fundamental para as religiões e para as igrejas é o de adotarem o pensamento analítico sem que ocorra o "desencantamento do mundo", com a imposição da racionalidade instrumental, estimulada pela cultura do capitalismo.

\section{Metamorfoses do sagrado}

Um fato social incontestável dos países ocidentais de tradição cristã é a crise representada pela metamorfose do sagrado (Martín Velasco,1999). Os indicadores dessa crise incluem a queda da prática regular das religiões tradicionais, a adoção de práticas oriundas de outras tradições espirituais, o surgimento e o avanço de novos movimentos religiosos e, ao mesmo tempo, da indiferença religiosa. $\mathrm{Na}$ escala social de valores, o fator religioso passa ao segundo plano, com o aprofundamento da secularização. Nesse contexto, a Igreja, como instituição, passa por um processo de esvaziamento, e muitos de seus ex-adeptos adotam a opção do believing without belonging (crer sem pertencer à instituição religiosa).

A deseclesialização e a secularização avançam no Ocidente, em paralelo ao crescimento de novas formas de vivência religiosa. Um traço comum nesses fenômenos é o deslocamento da experiência religiosa para o indivíduo, sem a mediação das instituições, dentro da lógica da valorização da subjetividade. As religiões que tiveram a capacidade de orientar a vida social como um todo, hoje são apenas uma das possíveis fontes de sentido para o mundo e a pessoa. Amodernidade obriga, pois, as Igrejas a renunciarem a qualquer pretensão de impor à sociedade seus princípios e normas.

\section{O fim do eurocentrismo eclesiástico}

Em 1980, a ICR só contava com $44 \%$ de seus integrantes na Europa e na América do Norte. Hoje, há 35\% de católicos no Ocidente, 
65\% na África, na América e na Ásia. Ou seja, antes de 2010, mais de dois terços dos católicos não serão mais originários da tradição greco-latina. Nos EUA, a maioria dos católicos será hispânica.

A Igreja sofre a concorrência, no Terceiro Mundo, de seitas e igrejas evangélicas, sobretudo pentecostais.Essa concorrência acontece, também, na Ásia e na África, em virtude do Islamismo. De acordo com os dados mais recentes, o Cristianismo, nas suas vertentes católica e evangélica, possui, hoje, cerca de dois bilhões de seguidores no mundo, dos quais 553 milhões na Europa, 802 milhões nas Américas, 351 milhões na África, 290 milhões na Ásia e 24 milhões na Oceania. O Islamismo possui 1,3 bilhão de adeptos, caminhando para se tornar, a médio e longo prazo, a maior religião do mundo, quanto ao número de integrantes. Seguem, pela ordem, o hinduísmo (900 milhões); o universo dos cidadãos que se declaram agnósticos e pessoas que se declaram não religiosas (850 milhões) e o Budismo (360 milhões).

Em alguns países do Primeiro Mundo, o catolicismo sofre uma erosão interna, com a perda de padres, que discordam do celibato obrigatório, e de leigos, que optam pela crença não institucional ou se tornam indiferentes do ponto de vista religioso. Na França, a população católica é de 40 milhões, dos quais a metade deixou de ser praticante. Nos Estados Unidos, o número de padres passou de 58.632, em 1965, para 43.634 em 2003. A população católica diminuiu de $24 \%$, em 1965 , para $22 \%$, em 2003. No mundo, o número de padres passou de 419 mil em 1970, para 405.178 em 2002. Contudo, a população católica evoluiu de 653 milhões, em 1965, para 1,045 bilhão, em 2003.

\section{A luta pela hegemonia religiosa}

A Igreja continua sendo a instituição mais confiável para a maioria dos latino-americanos (72\%), seguida da televisão (49\%) e das Forças Armadas (38\%), enquanto somente $24 \%$ confiam no Congresso e $21 \%$ nos partidos políticos, de acordo com pesquisa por amostragem realizada, no segundo semestre de 2001, pela ONG chilena Corporación Latinobarometro, especializada em pesquisas sociais de âmbito continental.

É oportuno destacar que a América Latina foi o primeiro continente a se mobilizar para a implementação das reformas eclesiais aprovadas pelo Concílio Vaticano II e que, neste início de século XXI, esse mesmo continente abriga o maior número de católicos no mundo. No cenário brasileiro, paralelamente, outro fenômeno tem levado a Igreja a rever suas 
estratégias de atuação religiosa, com consequiências políticas. Trata-se da mudança do perfil religioso da sociedade, sobretudo nos últimos trinta anos, dentro de um processo denominado "pentecostalização brasileira" (Carranza Dávila , 2002). De acordo com o IBGE, em 1950, 93,5\% da população brasileira declararam-se católicos apostólicos romanos, 3,4\%, evangélicos; $1,6 \%$, mediúnicos/espiritualistas e $0,8 \%$, de outras religiões, com o mesmo percentual para os sem religião e sem declaração. Vinte anos depois, em 1970, 91,8\% disseram-se católicos, 5,2\%, evangélicos, 1,6\%, mediúnicos/espiritualistas, $1 \%$ de outras religiões e $0,8 \%$ sem religião e sem declaração. Em 1991, a população católica caiu para 83\%, a evangélica subiu para $10 \%$ e a mediúnica/espiritualistas caiu para $1,5 \%$; a das outras religiões diminuiu para $0,4 \%$, a dos sem religião atingiu $4,7 \%$ e a dos sem declaração, 0,4\%. Em 2000, declararam-se católicos 73\%; evangélicos, 15,4\%; mediúnicos/espiritualistas, $1,7 \%$; de outras religiões, 1,6\%, sem religião, 7,3\%, e sem declaração, 0,4\%.

Os dados religiosos no Censo Demográfico de 2000 definem a identidade religiosa dos declarantes, mas não a sua prática e nem mesmo a sua pertença a uma determinada igreja ou tradição religiosa. Com a modernização da sociedade, sobretudo nas cidades, onde vive a grande maioria da população, a identidade nacional foi separada da identidade católica. Desse modo, muitas pessoas, embora batizadas na Igreja, podem declararse não católicas, sem se sentirem discriminadas. A relativa queda do percentual de mediúnicos/espiritualistas seria, por sua vez, causada pelo seu sincretismo com a fé católica.

O estado brasileiro com a maior perda de católicos, e com maior aumento da população autodeclarada sem religião é o Rio de Janeiro, enquanto os estados com maiores índices de identificação com o Catolicismo são o Piauí, Ceará, Paraíba, Alagoas e Maranhão. Nesse contexto, de acordo com uma análise de maio de 2002, os dados mostram que o Brasil continua sendo majoritariamente cristão (católico e evangélico). A novidade é que cresceu de 1,9\% para 7,3\%, nos últimos 20 anos, o número de brasileiros que se declaram sem religião. O Atlas de Filiação Religiosa e Indicadores Sociais do Brasil, publicado em julho de 2003, aponta que o maior crescimento dos evangélicos, e das pessoas que afirmam não ter nenhuma religião no país, ocorre principalmente nas áreas de fronteira agrícola no norte e centro-oeste e na periferia das grandes cidades brasileiras. Nessas áreas, a filiação religiosa tem, segundo os pesquisadores do Atlas, uma relação direta com o processo migratório. Esse processo é confirmado por outra pesquisa do IBGE, indicando que, a cada ano, a população 
católica reduziu-se em um ponto percentual, com a maioria dos egressos optando por igrejas evangélicas. Nos municípios de São Paulo e do Rio de Janeiro, e em outras regiões metropolitanas do país, uma de cada quatro pessoas deixou o Catolicismo, nos últimos vinte anos.

\section{A PERSISTÊNCIA DO DÉFICIT DEMOCRÁTICO}

A Igreja continua, por outra parte, a vivenciar, internamente, um déficit democrático, sobretudo com relação à livre investigação teológica, à situação das mulheres, à obrigação do celibato dos padres e a uma moral sexual que muitos consideram ultrapassada.

Quanto à investigação científica teológica, é constante a edição de censuras e penas impostas a teólogos e a teólogas, por parte da Congregação para a Doutrina da Fé (antigo Santo Ofício). Seguindo o caminho de Hans Küng e Leonardo Boff, o teólogo espanhol Juan Tamayo Acosta tornou-se, no início deste ano, o primeiro a ser censurado, no século XXI, por esse organismo da Cúria Romana, por causa das teses defendidas em seu livro Deus e Jesus, publicado em 2000. Foi censurado sem ter conhecimento do processo, sem ser chamado a depor, ou seja, sem direito a recurso e à defesa. Foi acusado de adotar uma posição racionalista "que conduz necessariamente ao ateísmo" e de seguir "posições ambíguas" sobre a ressurreição de Jesus Cristo, além de ser repreendido por dar "muitas entrevistas à imprensa". Adecisão do cardeal Ratzinger de punir Tamayo resultou no protesto de dezenas de outros teólogos, também ligados à Teologia Política européia e à Teologia latino-americana da Libertação, entre os quais os próprios Hans Küng e Leonardo Boff, além de Marciano Vidal, Benjamin Forcano, Manuel Fraijó, Xavier Picaza, José Maria Diéz Alégria, José Maria Castillo, Juan Antonio Estrada e Juan Bosch.

Forcano publicou, em 1981, seu livro Nova Época Sexual, que foi proibido pela Congregação para a Doutrina da Fé. Afastado da Congregação Claretiana, com mais cinco companheiros, e retirado da direção da revista Missão Aberta, foi recebido em São Félix do Araguaia/MT, por d. Pedro Casaldáliga. Manuel Fraijo, jesuíta, defendeu publicamente Hans Küng quando esse teólogo foi afastado de sua cátedra universitária em Friburgo. Advertido por Ratzinger, manteve o apoio a Küng e, depois, afastou-se do sacerdócio.

Xavier Picaza, mercedário e professor da Pontifícia Universidade Católica de Salamanca, foi condenado em 1984 e proibido de ensinar Teologia por causa de seu livro As origens de Jesus (publicado em 
1978). Foi acusado de não ter deixado claro "que Jesus é o Filho eterno do Pai, nem que o Espírito Santo seja a terceira pessoa da Trindade e por ter duvidado da divindade de Cristo”. José Maria Diéz Alegria, jesuíta, professor da Universidade Gregoriana de Roma, foi afastado de sua cátedra e da Companhia de Jesus, por dois anos, por causa de suas opiniões sobre a Igreja e o marxismo, expressas no livro Eu creio na esperança, publicado nos anos setenta. Depois de dois anos, não se retratou e teve que deixar sua ordem. José Maria Castillo, também jesuita e professor da Faculdade de Teologia de Granada (Espanha), foi afastado das aulas em virtude de suas idéias sobre a Trindade e a pessoa de Jesus. Juan Antonio Estrada, também jesuíta, perdeu em 1988 sua cátedra em Granada, "por suas opiniões contrárias ao dogma católico". O dominicano e professor da Faculdade de Teologia de Valência (Espanha) Juan Bosch, por sua vez, foi censurado pelo Vaticano por ter-se solidarizado com o "Documento de Colônia", publicado na Alemanha, com a assinatura de centenas de teólogos, que exigiam a liberdade de expressão no interior da Igreja.

A inquisição contra Hans Küng é mais antiga. Nascido em 1928, em Sursee (Suíça), graduou-se em Filosofia em 1951, na Pontifícia Universidade Gregoriana de Roma, com uma dissertação sobre o humanismo ateu de Jean-Paul Sartre e em Teologia, em 1959 na mesma universidade, com um trabalho sobre a doutrina da justificação do teólogo evangélico Karl Barth. Doutorou-se em Teologia na Sorbonne, com uma tese sobre o mesmo autor, que lhe valeu a abertura do dossiê Küng no Santo Ofício do Vaticano. Foi nomeado oficialmente, em 1962, pelo papa João XXIII, como perito do Concílio Vaticano II. Apesar disso, foi processado em 1963, por causa do seu livro Estruturas da Igreja, e advertido em 1965 em razão de uma conferência sobre a "Veracidade da Igreja". Em 1967, o Vaticano confirmou o decreto, proibindo a tradução e a distribuição do seu livro A Igreja. Uma nova censura foi aplicada em maio de 1970, em reação a um artigo sobre os casamentos mistos entre católicos e pessoas de outras religiões. No ano seguinte, seu livro Infalivel? uma interrogação, em que questiona a infalibilidade do papa, o levou a ser interrogado por bispos e teólogos da Igreja alemã. Nesse mesmo ano, recebeu a solidariedade de trezentos teólogos católicos e protestantes. Em 1974, publicou seu livro Ser cristão, contra o qual a Conferência Episcopal alemã divulgou três declarações. Finalmente, em 1979, o Vaticano revogou a sua autorização para ensinar como docente católico.

"Critiquei a Igreja - afirmou -, não por ter-me afastado dela, mas por ter-me comprometido com ela. A Igreja foi e continua sendo importante para mim, mas nunca foi a instância suprema, nem o será no 
futuro. A Igreja só tem sentido no serviço ao homem e, definitivamente, ao próprio Deus. E a Igreja cristã só tem sentido quando não se baseia em leis e dogmas autofabricados, mas segundo a norma do Evangelho de Jesus Cristo". E acrescentou: "é possível que não agrade aos atuais hierarcas e teólogos ouvir que Jesus não esteja ao lado da hierarquia e que foi liquidado por ela, em colaboração com os poderes políticos. Contudo, tal afirmação representa uma verdade histórica que ninguém nega hoje e de que poderiam ser retiradas conseqüências práticas".

Um caso menos divulgado de censura e de punição atingiu, recentemente, a teóloga brasileira Ivone Gebara, uma das mais conhecidas representantes da Teologia feminista. Justamente por esse motivo, foi censurada pelo Vaticano e obrigada a refazer seus estudos teológicos, em Roma. Sua Congregação conseguiu, contudo, que a sua "pena" fosse cumprida na Bélgica.

\section{JOÃO PAULO II, 25 ANOS}

\section{A trajetória do papa}

O teólogo chileno Pablo Richard utiliza a expressão "neoconservadorismo progressista" para caracterizar a ideologia hegemônica nos 25 anos do Pontificado de João Paulo II. Ele imprimiu, ao seu longo governo, uma marca contraditória à Igreja, representada por práticas autoritárias internas e por discursos e gestos reformistas ad extra. A sua biografia pessoal é marcada por vários traumas: sofreu um atentado terrorista em 13 de maio de 1981, na Praça de São Pedro, que lhe valeu a retirada de uma parte do intestino; contraiu um tumor intestinal em 1992, teve uma fratura no colo do fêmur em 1994 e uma apendicite, em 1996, além de padecer da doença de Parkinson. Na juventude, já havia enfrentado a experiência do nazismo e do stalinismo. Tudo isso contribuiu para humanizar, ainda mais, a sua figura como papa.

De igual maneira, esse carisma refletiu-se no sucesso de suas viagens, que assumiram um caráter estratégico de afirmação da Igreja, não apenas como instância romana, mas, sobretudo, como uma referência universal. Suas viagens representaram não apenas momentos pastorais e espirituais de alta intensidade, mas também gestos sociopolíticos para afirmar o papel da Igreja como o único referencial de unidade em um mundo dividido. Em sua visão de mundo, João Paulo II adota uma abordagem pre- 
dominantemente culturalista e religiosa para explicar a crise civilizatória: na base de todos os problemas encontra-se o abandono da religião. De certa forma, a mensagem é que somente a Igreja pode salvar o mundo do desastre. Do ponto de vista da moral sexual familiar, o papa restaurou a doutrina tradicional, sem conseguir, contudo, que a maioria dos católicos deixasse de recorrer, por exemplo, aos novos métodos de controle de natalidade. Para João Paulo II, a família é base de todas as virtudes e o espaço fundamental de regulação moral da sociedade.

É o que expressa, entre outros textos de sua autoria, a carta apostólica sobre a família, publicada em 1981. Nela, o papa sintetiza sua visão sobre a moral conjugal e sexual. Suas posições foram confirmadas no Catecismo Universal, de 1992, e em fóruns internacionais, como a Conferência Mundial sobre a População e o Desenvolvimento, da ONU, no Cairo, em 1994. O Catecismo condena o divórcio, a união livre, o casamento por experiência e as práticas homossexuais, consideradas "um comportamento intrinsecamente desordenado porque fecha o ato sexual ao dom da vida e não procede de uma complementariedade afetiva e sexual verdadeira". Ao receber cientistas, em 1983, o papa qualificou a contracepção e o aborto como "os dois frutos de uma mesma planta". Contrariando algumas correntes científicas, reafirmou a posição oficial da Igreja de que um novo ser humano surge desde a fecundação do óvulo e que o aborto representa o assassinato de uma criança não nascida. Do mesmo modo, o Catecismo Universal prescreve que a cooperação formal com o aborto é um delito contra a vida, gerando, para o responsável, a pena canônica da excomunhão. O papa também condena a procriação artificial, as manipulações genéticas, a clonagem e o tráfico de embriões.

João Paulo II exerceu, ao mesmo tempo, um importante papel estratégico na derrocada dos regimes comunistas no Leste europeu, como confirmou o próprio Mikhail Gorbatchev, em 1991: "podemos afirmar hoje que tudo o que aconteceu no Leste europeu, no decorrer dos últimos anos, só foi possível pela presença desse papa e do papel eminente que ele desempenhou, inclusive no plano político, no cenário mundial”. Suas três primeiras viagens à Polônia, em 1979, 1983 e 1981, contribuíram para a erosão final do governo comunista, influindo igualmente na desestabilização dos demais regimes desse tipo no Leste europeu. Desse modo, a diplomacia do atual papa representa uma ruptura dos métodos diplomáticos de seus antecessores João XXIII (1958-1963) e Paulo VI (1963-1978), baseados no diálogo tático e discreto com os Estados comunistas. Praticamente o mesmo discurso feito na Polônia nos anos oitenta, foi repetido em Havana, diante de Fidel Castro, em 25 de janeiro de 1998. 


\section{A política externa do Vaticano}

A Igreja Católica é a única instituição confessional do mundo a ter acesso às relações diplomáticas. De acordo com o secretário de Assuntos com os Estados, do Vaticano, o arcebispo francês Jean-Louis Tauran, isso se deve, em primeiro lugar, à sua história, à sua organização universal e transnacional e, também, ao seu chefe que, a partir da sua eleição em conclave, adquire um caráter internacional.

A interação da Igreja Católica com os demais atores internacionais não se dá, propriamente, por meio da Igreja, nem pelo Estado do Vaticano, mas pela Santa Sé (formada pelo papa e a Cúria Romana). De acordo com o Código de Direito Canônico (cân. 361), a expressão "Santa Sé" inclui "não só o Romano Pontífice, mas também a Secretaria de Estado, o Conselho para os Negócios Públicos da Igreja e os demais organismos da Cúria Romana". A Cúria é a administração central da Igreja. O mesmo Código afirma, no cân. 1131, que a Igreja Católica e a Sé Apostólica "são pessoas morais pela própria ordenação divina". O contato entre a Santa Sé e a comunidade internacional nasceu no contexto dos Concílios Ecumênicos: a figura do Núncio Apostólico (embaixador do papa), com uma missão diplomática junto a um determinado governo e com uma missão eclesial junto a uma igreja particular, já existia no ano 453 , no final do Concílio de Calcedônia. No século XVI, a realidade internacional é impactada pelo surgimento do Estado-Nação. A diplomacia adapta-se à nova situação. Em 1701, o papa Clemente XI institui a Academia dos Nobres Eclesiásticos, para formar os representantes pontifícios junto a outros governos. O Congresso de Viena (1814/1815) - responsável pela reorganização geopolítica da Europa, após a derrota de Napoleão Bonaparte - dá precedência, nos debates, ao representante do papa.

A legitimidade internacional da Santa Sé é, majoritariamente, reconhecida. A Santa Sé tem personalidade jurídica internacional (é a única confissão religiosa a ter esse status) e se apresenta como uma "autoridade moral soberana e independente", por meio dos canais da diplomacia bilateral (que inclui relações diplomáticas com 176 países; assinatura de concordatas e de acordos) e da diplomacia multilateral (relações com a ONU, com a Comunidade Européia e com outras organizações).

Entre os países mais conhecidos, apenas a China, a Arábia Saudita e o Vietnã ainda não estabeleceram relações diplomáticas com a Santa Sé. Essas relações são dirigidas e executadas pela Secretaria de Estado, cuja origem remonta ao século XV e que tem duas secções: a 
Secção dos Assuntos Gerais e a Secção das Relações de Estado, que integram o Conselho dos Assuntos Públicos da Igreja. A Segunda Secção cuida das questões que envolvem a Igreja e os governos civis, além das organizações multilaterais.

\section{Estratégias da diplomacia vaticana}

A dimensão política do discurso religioso apresenta uma extrema dificuldade para a Ciência Política, na medida em que utiliza, de forma sincrética, conceitos e elementos baseados na fé (subjetividade) e na razão (objetividade). Nesse sentido, analisar as estratégias políticas religiosas no espaço público requer, necessariamente, um exercício de análise do discurso, na tentativa de distinguir o que é especificamente religioso e o que é especificamente político.

Definida a estratégia como "uma coordenação de atividades complexas que visam a obtenção de um determinado resultado", a política externa do Vaticano está voltada, em termos gerais, para garantir espaços de influência em todos os fóruns nacionais e internacionais em que a sua visão de mundo e seus interesses estejam envolvidos. Isso inclui, por exemplo, todo e qualquer fórum que trate de questões ligadas à vida, desde seu momento inicial até à morte; e que também trate da liberdade religiosa, da justiça e da paz. Os interesses da Igreja têm um caráter transnacional e se concentram, essencialmente, na abertura ou na consolidação de espaços para a sua ação evangelizadora. Nesse sentido, as estratégias da diplomacia vaticana não estão voltadas, na história contemporânea, para a conquista do poder político direto, mas para garantir, no espaço interno dos Estados e no plano mundial, o grau de influência e as propostas da Igreja. Nesse contexto, há uma correspondência entre os momentos da história da Igreja e os modelos e paradigmas eclesiásticos.

Na história do Cristianismo (Comblin, 2003), podem ser identificados basicamente três períodos: o primeiro é o das perseguições até à conversão de Constantino, caracterizado pelo princípio de resistência à ordem estabelecida; o segundo - e mais longo - refere-se ao período da Cristandade que começou com Constantino e prevaleceu praticamente até a Revolução Francesa; nele, o Cristianismo era um dos atores principais da ordem dominante. O terceiro envolve todo o processo histórico pós-1789 até os dias atuais, em que o Cristianismo é confrontado com novos desafios, entre os quais a deseclesialização e a secularização. 
Durante todo esse processo histórico, a Igreja, como instituição, foi construindo o seu modelo próprio de diplomacia, com as seguintes características básicas, entre outras: estável; conciliatória; silenciosa; baseada em pequenos e gradativos passos; com o menor custo possível para a imagem da instituição; reforçadora da imagem da Igreja como uma instituição unificadora, a serviço de toda a humanidade. Uma das tradições da Santa Sé é, também, a de nunca tomar a iniciativa, nem de iniciar, nem de romper, as relações diplomáticas com qualquer país.

\section{As viagens do papa como dado estratégico}

Nas estratégias de política externa do Vaticano, as viagens do papa assumem um papel fundamental, do ponto de vista pastoral-religioso, mediático e político. Os périplos pontifícios no século XX começaram no período de 4 a 6 de janeiro de 1964, com a viagem de Paulo VI à Terra Santa, três anos antes da Guerra dos Seis Dias. Até então, o único pontífice a deixar o território romano fora o papa Pio VII, no começo do século XIX.

Paulo VI fez também uma histórica visita à sede da ONU, em $4 \mathrm{e}$ 5 de outubro de 1965, a convite do secretário-geral, U Thant. Diante de representantes da maioria dos países membros (somente a Albânia, então stalinista, boicotou a sessão de 4 de outubro), o papa afirmou: "Esse encontro possui um duplo caráter: de simplicidade e de grandeza; de simplicidade, porque quem vos fala é um homem como vós; ele é vosso irmão e mesmo um dos menores entre vós, que representais Estados soberanos, uma vez que só é investido de uma minúscula e quase simbólica soberania temporal, o mínimo necessário para ser livre para exercer a sua missão espiritual e para assegurar, a todos que com ele tratam, que é independente diante de toda soberania deste mundo. Ele não tem nenhuma soberania temporal, nenhuma ambição de competir convosco". Em seguida, pediu aos Estados que se empenhassem em favor da paz e proclamou duas vezes: "Nunca mais a guerra! Nunca mais a guerra !".

Depois do brevíssimo governo de João Paulo I, seu sucessor João Paulo II fez das viagens um de seus principais instrumentos a serviço da Igreja. O Brasil foi visitado por ele três vezes.

\section{Igreja e Teorias das Relações Internacionais}

Em que modelo teórico de Relações Internacionais poderíamos incluir a política externa do Vaticano? Uma resposta apressada possivelmente a qualificaria como wilsoniana e idealista. No entanto, o estudo dos 
eventos dessa política específica leva-nos a uma caracterização mais complexa. Em nome de seus interesses institucionais e de sua missão, a Santa Sé tem adotado posições realistas em sua foreign policy, enquanto promove uma visão idealista de mundo.

Esse realismo manifestou-se, de modo bastante evidente, durante a guerra fria, nos pontificados de João XXIII a Paulo VI, com a chamada Ostpolitik do Vaticano, voltada para os Estados de regime socialista do Leste europeu. João Paulo II deu continuidade a essa política, de que já participava em seu país natal, como arcebispo de Cracóvia. Tendo como referencial de resistência ao comunismo suas freqüentes viagens à Polônia, Karol Wojtyla torna-se, então, uma figura-chave, do ponto de vista estratégico, no processo de queda dos regimes autoritários do Leste europeu. O papa apóia, desde o começo, o sindicato Solidarnosc, de Lech Walesa, e reage, junto a Leonid Brejnev, contra as ameaças de invasão da Polônia pelas tropas soviéticas. Em dezembro de 1989 recebe, no Vaticano, o líder soviético Mikhail Gorbatchev, dois anos antes da débâcle da URSS, em 1991. No conflito da ex-Iugoslávia, o Papa também participa do jogo de xadrez estratégico e se antecipa, taticamente, aos hegêmonas ocidentais, ao reconhecer, em 13 de janeiro de 1992, a independência da Croácia e da Eslovênia. Do mesmo modo, no Ocidente, um difícil processo de negociação levaria o papa a visitar Cuba, em janeiro de 1998.

Outro exemplo de realismo político do Vaticano é o relacionamento de seus representantes diplomáticos com os governos da Argentina e do Chile, durante as ditaduras militares das décadas de setenta e oitenta. No Chile, o general Pinochet teve, entre os seus principais aliados, o então Núncio Apostólico, arcebispo Ângelo Sodano, hoje a segunda autoridade do Vaticano, como secretário de Estado. Graças a essa amizade, a Santa Sé formalizou, de imediato, junto às autoridades britânicas, o primeiro pedido para que o ex-ditador chileno fosse libertado. Do mesmo modo, na Argentina, os generais encontraram no Núncio Apostólico, d. Pio Laghi, um leal e permanente parceiro. Aditadura argentina repassava a Laghi informações privilegiadas. Esses vínculos de Laghi com a ditadura levou a Associação das Mães da Praça de Maio a processá-lo junto à Justiça italiana, por considerá-lo omisso diante das violações dos direitos humanos, no regime de exceção. Neste momento, a Santa Sé examina também, de forma realista e pragmática, a possibilidade de uma reconciliação com a República Popular da China, admitindo, inclusive, o reconhecimento da tese chinesa de soberania sobre Taiwan. Além de aceitar essa tese, o governo chinês exige, da Santa Sé, o compromisso de não favorecer a campanha do Dalai Lama em favor da autonomia do Tibet. 
Por outra parte, a diplomacia vaticana vem realizando negociações, na ONU, para transformar o Vaticano de observador permanente em membro pleno das Nações Unidas.

\section{Convergências e divergências entre EUA e Vaticano}

Desde o momento em que resolveram levar à prática o que consideram o seu destino manifesto, os EUA sempre tiveram na Santa Sé um de seus principais aliados estratégicos. Essa aliança entre a Casa Branca e o Vaticano é o dado histórico preponderante no seu relacionamento bilateral. Os principais pontos de convergência, acentuados nos governos republicanos de Ronald Reagan, George Bush e do seu filho George Walker Bush: incluem, além do anti-comunismo, principalmente questões morais, como a rejeição ao aborto.

As questões centrais de divergência concentram-se, hoje, na posição contrária do papa e da Santa Sé aos eixos da Doutrina Bush e à política de intervenção preventiva dos EUA em países que seu governo considere como integrantes do "eixo do mal"; e na questão da economia e das políticas de ajuste estrutural, referenciadas exclusivamente no mercado. Nesse aspecto específico, um caso paradigmático é o contencioso entre o Vaticano e Washington em torno da recente invasão do Iraque. O papa opôs-se, desde o início, à decisão de Bush de descartar a ONU do affaire iraquiano e defendeu explicitamente o não esgotamento das possibilidades de uma saída negociada com o regime de Saddam Hussein. Deu sua contribuição particular nesse sentido, ao enviar dois negociadores com mensagens especiais para Bush e Saddam. Os enviados foram os cardeais Roger Etchegaray, a Bagdá, e Pio Laghi, a Washington.

O papa João Paulo II assumiu uma posição contrária à dos EUA e da Inglaterra, diante da invasão do Iraque, basicamente por dois motivos: éticos e espirituais, e pragmáticos. Reafirmou os princípios que o Concílio Vaticano II já havia aprovado nos anos sessenta: "todo ato de guerra que leve indistintamente à destruição de cidades inteiras ou de vastas regiões, com os seus habitantes, é um crime contra Deus e contra o próprio homem, que deve ser condenado firmemente e sem hesitação". Na posição do papa, no caso do Iraque, pesaram também motivos estratégicos: a ICR considera fundamental um bom relacionamento com os países islâmicos. O Islamismo tende a ser, a médio prazo, a religião com maior número de adeptos no mundo. A ICR é herdeira da doutrina da guerra justa (Tomás de Aquino). Mas, modernamente, já a entende de outra maneira: defende o 
direito de legítima defesa nacional, mas somente após o esgotamento de todas as possibilidades de solução pacífica para os conflitos. Essa legítima defesa só pode ser acionada em resposta a uma agressão armada atual e não apenas potencial (ou seja, a Igreja é contra a chamada "guerra preventiva"). Do mesmo modo, a guerra deve ser limitada, e não total, e não deve causar um mal maior do que o bem a ser defendido.

\section{A sucessão do papa}

Um colégio eleitoral majoritariamente conservador e multinacional elegerá o sucessor de João Paulo II. Em termos geográficos, provém de todos os continentes e inclui cardeais atuantes em contextos sociais, econômicos, culturais e políticos bastante diferentes como, por exemplo, as hostilidades inter-religiosas na Índia, a pobreza em Gana, a guerra civil no Sudão, os conflitos étnicos na Nigéria e as tensões políticas na Guatemala. Ao todo, o Colégio dos Cardeais representa 69 países. Os europeus hegemonizam o conclave, que elegerá o novo papa, com 66 cardeais eleitores, em 135. O maior bloco individual é o italiano, com 23 eleitores (17\% do total, comparados com $23 \%$ na última eleição, em 1978). A América Latina detém 17,8\% do total do conclave, com 24 cardeais eleitores. A Ásia e a África possuem treze eleitores cada uma, e a América do Norte, 14, dos quais 11 norte-americanos. Os eleitores da Cúria Romana são 34 (25\% do total), cinco dos quais completarão oitenta anos em 2004 e ficarão fora da lista eleitoral, se o papa não morrer até lá.

O critério geopolítico, com base na nacionalidade, deixou de ser absoluto na eleição do sucessor do papa. O que predomina agora são as alianças transversais entre grupos de cardeais da Europa e de outros continentes sobre temas considerados vitais para o futuro da Igreja. Os conservadores pretendem dar continuidade à atual política de João Paulo II, baseada no reforço da ortodoxia interna e na manutenção do atual perfil "neoprogressista conservador" ad extra. Já os reformadores defendem a convocação de um novo Concílio Ecumênico, o Vaticano III, mudanças na Cúria Romana, novas modalidades de exercício da missão papal, incluindo mudanças no diálogo com os bispos, com outras Igrejas e religiões, além da reafirmação das críticas da Igreja à doutrina do neoliberalismo. Vários pesquisadores afirmam que existiria uma tendência, na história das eleições pontifícias, de alternância entre um Pontificado longo e outro curto. Desse modo, os cardeais prefeririam eleger um papa idoso, embora com saúde, como elemento de transição, depois de 25 anos de governo de João Paulo II. 
Os vaticanistas apontam como candidato preferido dos setores progressistas o cardeal de Milão, d. Carlo Maria Martini, jesuíta, com 76 anos. Outro nome citado, nessa corrente, é o arcebispo de Tegucigalpa (Honduras), d. Oscar Andrés Rodríguez Maradiaga, 61 anos, salesiano, poliglota e ex-secretário-geral e presidente do Conselho Episcopal Latinoamericano (Celam), considerado de caráter conciliador. Um reforço para essa candidatura é o fato de que mais da metade dos católicos vive na América Latina. Ainda no mundo subdesenvolvido, a candidatura africana mais comentada é a do cardeal nigeriano Francis Arinze, considerado um pioneiro no diálogo entre o catolicismo e as religiões tradicionais africanas. Já entre os conservadores, o nome mais noticiado é o do cardeal Giovanni Battista Re, secretário da Congregação dos Bispos. Outro nome lembrado é o do cardeal de Bologna, d. Giacomo Biffi, apoiado pelas correntes integristas e por movimentos como Comunhão e Libertação e Opus Dei. São também lembrados, entre os vaticanistas, os cardeais Dario Castrillón Hoyos, colombiano, responsável pelo Conselho Pontifício para a Família e o italiano Dionige Tettamanzi, arcebispo de Gênova, considerado um reformador moderado. De todo modo, segundo um ditado sempre lembrado no Vaticano, "quem entra no conclave como papa, acaba saindo como cardeal".

\section{CONCLUSÃO}

Quem quer que seja o sucessor de João Paulo II, terá, diante si, o desafio de adequar o discurso da Igreja à atual realidade de um mundo globalizado, mais de trinta anos depois do Concílio Vaticano II; de reforçar o diálogo inter-religioso; de adotar novos métodos de trabalho, para dentro e para fora, e que consigam dar uma resposta aos desafios da secularização e da deseclesialização.

A nova sociedade civil intra-eclesiástica continuará pressionando em favor de outra concepção de Igreja, horizontal e democrática; continuará a questionar o monopólio masculino na atividade sacerdotal e a reivindicar a revisão da lei do celibato obrigatório. Outra demanda que se acentua é a da revalorização dos símbolos, numa sociedade desencantada. Isso significa reduzir o peso da burocracia institucional e recuperar o potencial simbólico subjacente à instituição eclesiástica. No plano das relações internacionais, a política externa do Vaticano é desafiada a se legitimar junto aos setores majoritários da população mundial, que continuam marginalizados e excluídos das decisões, sobretudo econômicas, que lhes 
dizem respeito. Para tanto, deverá ser reafirmado o discurso da ética social, em todas as instâncias, bilaterais e multilaterais.

Duas recentes pesquisas revelam a expectativa dos leigos católicos com relação ao futuro da Igreja: a primeira, realizada por Michael Hout e Andrew Greeley, em 2002, em seis países (Espanha, Irlanda, Estados Unidos, Itália, Polônia e Filipinas), incluiu sete perguntas: "O que você considera mais importante no futuro papa: que ele se dedique mais às pessoas comuns ou que se preocupe mais com os assuntos religiosos?; Os bispos são hoje escolhidos pelo Vaticano e, no passado, eram eleitos pelos padres e pelo povo. Você preferiria que a escolha continuasse como hoje ou que voltasse a ser como no passado?; O que você pensa sobre uma maior presença dos leigos como assessores do papa?; Você gostaria que o próximo papa desse maior poder de decisão aos bispos ou que continuasse a tomar a maioria das decisões na Igreja?; Você é a favor ou contra que o novo papa permita a ordenação de mulheres?; Você gostaria que o próximo papa fosse mais aberto para promover mudanças na Igreja ou você acha que está tudo bem na Igreja, hoje?".

A segunda pesquisa foi feita no primeiro semestre deste ano pelo jornal belga L'Appel, junto aos católicos da região belga de língua francesa, a Wallonie, sob a direção do professor Frédéric Antoine, da Universidade Católica de Louvain. Perguntados sobre o futuro do cristianismo, apenas 31\% declararam-se otimistas. Entre os que se disseram praticantes, $40 \%$ afirmaram ser otimistas e, entre os menos praticantes, $16 \%$. Mais de $60 \%$ disseram-se pessimistas quanto à evolução do relacionamento entre a juventude e o cristianismo, percentual esse de $60 \%$ quanto à prática religiosa, e de $61,5 \%$ quanto ao funcionamento da Igreja. Com relação a ética e a moral cristãs, $80 \%$ dos entrevistados disseram-se contrários à posição oficial da Igreja sobre a contracepção, e 50\% afirmaram ser contrários ao ponto de vista da Igreja sobre a eutanásia, o aborto e a procriação assistida. Mais de $80 \%$ admitem que os padres poderiam se casar e que os homens casados e as mulheres poderiam ser ordenados. Entre as pessoas entrevistadas, $66,5 \%$ consideram que não há bastante democracia na Igreja e 56,5\% afirmam que os leigos não participam ativamente da tomada de decisões na Igreja.

Já a primeira pesquisa indicou que os leigos mais jovens e com melhor instrução lideram as demandas por reformas na Igreja (58\% dos quais na Espanha e na Irlanda, países de grande tradição católica). Os espanhóis responderam positivamente em favor de uma maior autonomia para os bispos e por uma maior participação dos leigos em sua escolha, como também na ordenação de mulheres. Na Polônia, terra 
natal de João Paulo II, 58\% dos entrevistados disseram-se favoráveis a um papa "mais aberto às mudanças", assim como em favor do casamento opcional para os padres.

Quaisquer que sejam os rumos dados ao Catolicismo, no pósJoão Paulo II, parece evidente que nem todos os caminhos levam mais a Roma.

\author{
DERMI AZEVEDO é jornalista e mestre em Ciência Política \\ pela USP, onde também faz o doutorado.
}

\title{
REFERÊNCIAS BIBLIOGRÁFICAS
}

AMOROSO LIMA, Alceu (2001). Notas para a História do Centro Dom Vital. Rio de Janeiro: Edições Paulinas.

BAUM, Gregory (1990). "Le rapport Dumont: democratiser I'Église catholique”. Sociologie et Sociétés XXII (2), pp. 115-126.

BAZÁN, Pedro M. (1991). "Para entender la postmodernidad". Estudio Agustiniano 24. L 404. Selecciones de Teologia, pp. 154-160.

BIDEGAIN, Ana Maria (2002). Religious recomposition in global societies: the role of the Catholic Church in the Argentine and Colombian crises. Paper.

BOFF, Leonardo (1978). L'Égliseem génèse. Les communautés de reinventeni I'Église. Paris: Désclee de Brower.

BRUNEAU, Thomas and HEWITT, W.E. (1970). Catholicism and Political Action in Brazil: limitations and prospects. Paper.

CARRANZA DÁVILA, Brenda Maribel (2002). "Pentecostal Flames in contemporary Brazil". Concilium - Brazil: People and Church(es) no.3.

CERIS (2001). Tendências Atuais do Catolicismo: um estudo em seis regiões metropolitanas.

Relatório de pesquisa.

CLEARY, Edward (s/d). "The vitality of religion in a changing context". Latin American and Caribbean Contemporary Record. Vol. 8, Nova York: Holmes and Meier.

CNBB (1966/2003). Equipe de Assessoria Política. Análises de Conjuntura.

COMBLIN, José (2003). "Nuevo amanecer em la Iglesa”. Alternativas, Revista de análisis y reflexión teológica, pp. 23 a 50. Manágua: Editorial Lascasiana.

CONCÍLIO VATICANO II (1966). Documents conciliaires. Paris: Éditions du Centurion.

CONGAR, Yves (1970). L'Église de saint Augustin à l'époque moderne. Paris: Cerf.

DELLA CAVA, Ralph (1989). The people's church, the Vatican, and abertura. In: Alfred Stepan, Democratizing Brazil: problems of transition and consolidation. Nova York. Oxford: University Press. Pp. 143-167 (s/d) Catholicism and society in post-war Brazil. Nova York. Paper.

DESROCHE, Henri (1968). Sociologies Réligieuses. Paris: PUF.

DÍAS-SALAZAR, Rafael (2002). "Cambios religiosos y transformaciones sociales em um mundo globalizado". Entrevista a François Houart. Iglesia Viva 209, pp. 62-92.

DROGUS, Carol Ann (1997). Women, religion and social change in Brazil's popular church. Notre Dame: University of Notre Dame Press.

DUMAIS, Alfred (1998). "Ernst Troeltsch el la sécularisation de l'histoire". Laval Théologique et Philosophique 44 (3), pp. 279-282. 
GEBARA, Ivone (1999). Reflexions teologiques à partir du feminisme. Paris: L'Armailan.

HERVIEU-LÉGER, Danièle (1990). "De quelques récompositions culturelles du cathol cisme français". Sociologie et sociètés XXII (2), pp. 195-206.

HOUT, Michael e GREELEY, Andrew. The laity and reform in the church: a six nation study. Nova York. Paper.

JACOB, César Romero. RODRIGUES HEES, Dora. WANIEZ, Phillippe. BRUSTLEIN,Violette (2003). Atlas de filiação religiosa no Brasil. São Paulo: Edições Loyola/PUC-RJ.

KLAIBER, Jeffrey S.J (1998). The Church, dictatorships and democracy in Latin America. Maryknoll: Orbis Books.

KUNG, Hans (1995). Infallible? - No unanswered enquiry. Nova York: Continuum. (1968). L'Église. Paris: Descleé de Brouwer. (1963). Structures de l'Église. Paris: Desclée de Brouwer.

LATINOBAROMETRO (2002). Informe de prensa. Santiago. LEVINE, Daniel H (1992). Popular voices in Latin American Catholicism. Princeton: Princeton University Press.

LÖWY, Michael (2001). Rapports entre le religieux et Politique em Amérique Latine. Paper. MADURO, Otto (1983). Religião e luta de classes. Petrópolis: Vozes.

MAINWARING, Scott (1989). "Religion and popular protest in Latin America: contrasting experiences". In Susan Eckste, Ed. Power and popular protest: Latin American social movements. Berkeley: University of California Press, pp. 203-40.

MARTíN VELASCO, Juan (1999). "Metamorfosis de lo sagrado e futuro do cristianismo". Cuadernos aqui y ahora 37. Santander: Sal Terrae.

OLIVEIRA, Pedro A Ribeiro de (1985). Religião e dominação de classe. Petrópolis: Vozes.

RICHARD, Pablo (2000). Esperanza o caos? Fundamentos y alternatives para el siglo XXI. Santiago. Paper.

ROSTOW, Eugene. "The Role of the Vatican in the Modern World". L'Osservatore Romano, Estado do Vaticano, 30 de maio de 1968.

ROULEAU, Jean-Paul (1990). "Le catholicisme, vingi-cinq ans apres Vatican II". Sociologie et sociètés XXII (2), pp. 33-48.

ROY, Marie-Andrée (1990). "Le changement de la situation des femmes dans le catholicisme quebécois. Le rapport Dumont: démocraliser l'Église catholique". Sociologie et sociétés XXII (2), pp. 95-114.

SERBIN, Kenneth P(2001). Diálogos na sombra. São Paulo: Cia das Letras.

SESBOUÉ, Bernard (1999). Croire. Paris: Droguet et Ardant. (1999). L'Église comme institution. Paris: Droguet et Ardant. (1996). Nayez pas peur! Regards sur l'église et les ministères aujoud'hui. Paris: Desclée de Brouwer.

SOUSA LIMA, Luiz Gonzaga de (1979). Evolução política dos católicos e da Igreja no Brasil. Petrópolis: Vozes.

SMITH, Brian H (1998). Religious Politics in Latin America. Pentecostal vs. Catholic. Notre Dame: University of Notre Dame Press.

SMITH, Christian and PROKOPY, Joshua (1990). Latin American Religion in Motion. Nova York: Routledge.

STEPAN, Alfred (1987). Os militares: da Abertura à Nova República. Rio de Janeiro: Paz e Terra.

REMY, Jean (1990). "La hiérarchie catholique dans une société sécularisée". Sociologie et sociétés XXII, 2: 21-32.

TAMAYO ACOSTA, Juan (2000). Dios y Jesus. Madrid: Trotta.

TROELTSCH, Ernst (1976). The Social Teaching of the Christian Churches. Chicago e Londres: The University of Chicago Press.

TURCOTTE, Paul-André (1990). “À l'intersection de l'Église et de la secte, l'ordre 
réligieux". Sociologie et sociétés XXII (2).

VALLANCOURT, Jean-Guy (1990). "Contribuitions a la nauvelle sociologie du catholicisme”. Sociologie et sociétes XXII (2), pp. 5-12.

WEBER, Max (1965). Essais sur la théorie de la science. Paris: Plon. (1971). Économie et société. Paris: Plon.

(1967). L'Éthique Protestante et l'Esprit du Capitalisme. Paris: Plon. 